UNTAG Law Review (ULREV)

Volume 2, Issue 2, Nov 2018, PP 156-168

ISSN 2549-4910 (online) \& ISSN 2579-5279 (print)

http://jurnal.untagsmg.ac.id/indeks.php/ulrev/indeks

www.fakhukum.untagsmg.ac.id

\title{
DEMOCRACY "CHARACTER" LOCAL WISDOM BUILDING DEMOCRATIC POLITICAL AWARENESS OF CHARACTER "AKAL BUDI" AUTENTIK INDONESIA: A STUDY FROM EXPERIENCE OF GOVERNANCE SYSTEM OF REPUBLIC OF NAGARI IN WEST SUMATERA
}

\author{
Wendra Yunaldi \\ Lecturer at Faculty of Law Muhammadiyah West Sumatra University
}

\begin{abstract}
Although democracy has become the icon of the world, democracy still has the potential to accommodate in itself the values that are of national locality. The values then make democracy different from one country to another. There is a tendency to strengthen the role of the state by reducing the role of popular sovereignty, the development of democracy in the end tends to face the interests of the people themselves. Democracy is no longer a symbol of power politics in favor of the people. In order to maintain the consistency and content of morality or character in democracy, the values of indigenous peoples, such as Nagari which develops musyawarah, togetherness, control, supervision, togetherness, etc., have the potential to encourage the realization of an authentic and authentic Indonesian democratic system. Although institutionally, the development of institutional model of democracy has been good enough, but the institution or organization can not be separated from the substantial values that will lead and at the same time keep it running in the corridor of democracy. Because, the strong tendency of power tends to corrupt and abuse of power, then the values of morality that became the character of Indonesia should be affirmed in the democratic system adopted by the Indonesian nation today. Thus, the goal of realizing a politically just social life for all Indonesian people can be realized.
\end{abstract}

Keyworld : Democracy, Local Wisdom, and the Republic of Nagari

\section{INTRODUCTION}

\section{Our Democracy Problems}

The main problem of the implementation of Indonesian democracy today is the direction of development that tends to the good of the state, b eliminating people's cause. Democracy is no longer working for the sake of the people as sovereignty sovereign owners, which is the strengthening of the government (state) so as to place it more autonomously with full and 
constitutional power to do good actions according to the government, not the good according to the people. The ideologicalization of power as a result of the application of democracy without value and idealism has resulted in:

1. The whole life of the people is fully determined by the central government, while the position of local government and its people is no more as a legitimator for the establishment of absolute power in the central government.

2. State tools, in the name of the interests of the people, work in addition to strengthening their institutional identity, while at the same time strengthening the power network of its political parties within the state. So the interests of the sovereign people are merely complementary.

3. The loss of people's democratic rights as the owner of full sovereignty over the state, ranging from legalization efforts to all actions of the people to the formalization of community life by ignoring the rights of participation, independence, and self-reliance.

4. The sovereign is no longer a development orientation, development is top down, the government claims directly what and how the will of the people, the nrimo people, if not considered as an act against the will of the government.

5. The intimidating political style should not ask what the state has given you, but ask what you have given to the state. Unlike the democratic political style, do not ask what the people have given to the state, but ask what the state (government) has given to the sovereign. Therefore, the government (state) on behalf of the people with absolute power has full authority to take actions and policies related to the interests of social justice for all the people of Indonesia.

Some of the implications of the conception of democratic conception above, would be dangerous for the growth of democracy and the conception of the nation state of Indonesia that is civilized. Because, with the potential power of power tends to corrupt, power can act arbitrarily abuse of power, and power can issue policies and regulations to defend its interests, the potential power will act otherwise, better protect its own interests, than the people, always declaring himself working for the benefit of the people.

\section{Understanding}

The concept of democracy is the only social concept has globalized that is not restricted by the bounds of the locality of a nation. Democracy becomes a world icon adopted by almost all nation states that declare themselves as a sovereign state. Despite the "unlimited" nature of democracy, it can not be denied that the influence of the culture and culture of a country 
remains a color of democracy. Therefore, the application of democratic systems between America and Britain is different, as is the implementation of democracy between Brazil and Indonesia, respectively, attaching their cultural authenticity to democracy, which Soekarno calls the character (welstanchaung). ${ }^{1}$

And that character is then as the basis of differentiation between countries sesame adherents of democracy.

In a general sense, the term or concept of Democracy has been understood by almost all countries as a "government based on the interests of the people". The people are therefore seen as the highest sovereigns in a country. In spite of the fact, concrete or practice is done in different patterns and models, whether through state, federal and united forms, as well as forms of republican and parliamentary government, as well as in the form of people's legitimacy through direct election or representation systems. Democracy remains the icon of these countries, although later, the diversity of practices often leads to an anomaly situation with the principle of democracy itself.

Democracy according to Dahl is a political system that originally developed in Greece. Derived from the word demos which means people and cratia means government, then democracy is meant as "government by or from the people". Within the framework of sovereignty, democracy is meant by "the government is completely independent of the influence of the king's power or the power of the nobles." ${ }^{2}$ Democracy thus, firmly rejects monarchism and aristocracy because these two forms of government both annul the people's sovereignty in their government.

Therefore, the power of government is exercised in the perspective of "the sovereignty of the people", then the sovereign people equally affirm the role of values that live in society itself. Local wisdom is not only related to the social structure of a society, but rather it leads to a conception of liberalism, pluralism, and egalitarianism. Where the sovereign people, not only in terms of body or physical human, in it also contained human values consisting of mind, soul, and humanitarian rights to be declared as a whole human (sovereign) sovereign. Therefore, democracy then requires no distinction between social strata and social titles attached to a person, all the same.

Democracy will not be meaningless without the values that bind it. For, with the principle of

1 Safroeddin Bahar dan Nannie Hudawati (ed), Risalah Sidang Badang Penyelidik Usaha-Usaha Kemerdekaan Indonesia (BPUPKI) dan Panitia Persiapan Kemerdekaan Indonesia (PPKI) 28 Mei 1945-22 Agustus 1945, 1998, Jakarta, Sekretaria Negara Republik Indonesia, hlm.92

2 Robert A. Dahl, Analisa Sistem Politik Modern, terjemahan, Sahat Simamora, dari judul, Modern Political System, Bumi Aksara, Jakarta, 1985, hlm. 16 
the sovereign people embedded in its true identity, democracy must be exercised over a corridor that can prevent it from anarchism tendencies, since, the majority tend to impose its will on minority groups. ${ }^{3}$ The rational, utopian and idealistic definitions affect much of medieval theoretical, yet lose much of their influence when implemented in state practice.

The narrowness of the meaning of democracy by Anders Uhlin is called the minimalist definition ${ }^{4}$ contained in the concept of ancient Greek democracy resulted in the limited meaning of the concept of ancient Greek democracy on aspects of government and abstract power. In fact, democracy has a broad aspect that is concerned with the life of the people themselves. $^{5}$

Looking at the weaknesses of the maximalist democracy definition, experts especially post1950 s, try to reconstruct the definition into a more maximalist definition. ${ }^{6}$ The maximalist definition or procedural definition places democracy as an empirical, descriptive, and institutional concept. Schumpeter explains : An institutional plan to achieve political decisions in which individuals gain power to decide politics, in which individuals gain power to decide by means of a competitive struggle over the voice of the people" ${ }^{7}$

The people referred to are government of the people, by the people, for the people. ${ }^{8}$ Who has absolute power with strong representation to give political role to its representatives, both in government and legislative. According to Dahl, the ideal process of implementation of democracy will be seen on five criteria that can not be avoided if the government are:

1. equality of suffrage in making binding collective decisions, the privileges of every citizen should be considered in a balanced manner in determining the final decision,

2. active participation. The whole process of collective decision-making, including the stage of collective decision-making, including the determination of the agenda of work, every citizen should have equal and adequate opportunity in declaring his privileges in order to realize the final conclusion,

3. The exposure of the truth. In the time possible, because of the need for a decision, every citizen must have equal opportunity to carry out a logical assessment in order to achieve

3 Robert A. Dahl, Demokrasi dan Para Pengkritiknya, terjemahan, Yayasan Obor Indonesia, dari judul, Democracy and Its Critics, Yayasan Obor Indonesia, Jakarta, 1992, hlm. 43

4 Anders Uhlin, Oposisi Berserak: Arus Deras Demokratisasi Gelombang Ketiga di Indonesia, terjemahan, Rofik Suhud, dari judul, Indonesian and The Third Wave of Democratization The Indonesia Pro Democracy Movement in Changing Word, Mizan, Bandung, 1998, cet, ke-2, hlm. 9

5 Samuel P. Huntington, Partisipasi Politik di Negara Berkembang, terjemahan, Sahat Simamora, dari judul, No Easy Choice : Political Participation In Developing Countries, Rineka Cipta, Jakarta, 1990, hlm. 39

6 Anders Uhlin, loc.cit.

7 Ibid., hlm. 269

8 Wiliam D. Halsey and Bernard Johnston (eds), Collie's Encyclopedia, New York : Macmilan Educational Company, 1988, hlm. 75 
the most desirable outcomes,

4. final control of the agenda. The community must have the exclusive power to decide which issues should and should not, and coverage.

5. Society must cover all adults in relation to law. ${ }^{9}$

Based on Dahl's formulation above, the modern conception of democracy is no longer letting the government (state) act without involving the people. The occurrence of misconceptions that take place today, where with the system of representation, people's power asasiah taken over by the House of Representatives / DPD to the area, the will, aspiration, control and transparency of government (state) to the people become erased and lost. This situation is increasingly in perparah when the President with DPR / DPD / DPRD have the same political interests, then what happens then is merely Democracy Political Party Daulat, which further strengthens the state of democratic deficit. According to Daniel Sparingga:

Among political analysts, the five-year transition of democracy in Indonesia is characterized by what they are conceptualized with the term "deficit democracy". One of the most important parts of the analysis of this issue highlights the role of political parties that are perceived as less seriously implementing the reform agenda for the purpose of democracy. In general, political parties in Indonesia have lost their true ideological orientation to a meaningful change. Party elites are often involved in debates characterized by the uncertain ideological battlefield and power struggle. Both are mixed, often very manipulative for using ideological themes for a very political purpose, namely power for power. ${ }^{10}$

\section{Values of Local Wisdom in the Democracy of Indonesia: Learn from the Experience of the Republic of Nagari in Minangkabau}

Indonesia in the context of modern governance, has not reached the age of a century. Meanwhile, in the context of the nation under the great and small kingdoms have begun since the year $306 \mathrm{AD}$, ranging from sabang to merauke. The life of the nation in the monarchi political tradition, as it is experienced by other nations in the world, provides the experience of resources for Indonesia to live in a sophisticated political order. Because, the traditions of Unity of Indigenous People (KMHA) which reach 250 zelbesturendelanschappen and volkgemeenschappen. ${ }^{11}$ Local life is small, as Van Vollenhoven has argued : ${ }^{12}$

9 Robert A. Dahl, Dilema Demokrasi Pluralis, Antara Otonom dan Kontrol, terjemahan, Sahat Simamora, dari judul, "Dilemmas of Pluralist Democracy” Rajawali, Jakarta, 1985, hlm. 10-11

10 Daniel Sparringga, “ Partai Politik dan Transisi Demokrasi”, Pengantar, dalam, Thomas Meyer, Peran Partai Politik dalam Sebuah Demokrasi, 2012, Jakarta, Friedrich-Ebert-Stiftung (FES), hlm. 18-19

11 Penjelasan Pasal 18 UUD Tahun 1945

12 Dikutip dalam Bagir Manan, Beberapa Masalah Hukum Tata Negara Indonesia, 1997, Bandung, Alumni, hlm. 206 
.....that when the first Dutch trade fleet entered (and anchored) in the archipelago (Banten 1596),

the Indonesian state was not a wild and empty area (woest en ledig). In Indonesia at that time there has been the structure of society and government in the composition of tribe, village, republic and kingdom.

The structure of the governed society as stated by Van Vollenhoven shows how the Indonesian archipelago (later became Indonesia) has organized its social, political and governmental life in a modern way, even though it is not in written form. Glen Wright, sees the customary law contained in Indonesia with the various prerequisites of value contained in it is very modern.

Indonesian law is based on a civil law system incorporating elements of customary law and Dutch law. Prior to colonisation by the Dutch in the sixteenth century, Indonesia was ruled by numerous independent indigenous kingdoms, each with their own customary laws. Following independence in 1945, Indonesia started to develop its present legal system, infusing new laws with the precepts and concepts of existing laws. As such, customary law known as adat law remains a part of the modern Indonesian legal system. ${ }^{13}$

Even then, customary law is categorized modern in its day, because society has been arranged in legal relations in various aspects of life. Unlike other indigenous peoples in various countries. Where, their lives take place in a custom process not regulated by normative agreements. $^{14}$

Thomas E. Davitt's understanding and conclusions on several examples of the countries he put forward in his book. A distinctive difference when compared with the Minangkabau Traditional Law concept, the place where Nagari was born. These agreed values $\square \square$ become law even if not written, but in the maxim and mamangan, which develops orally from generation to generation, the legal counseling process continues over a considerable period of generations.

Nagari as a symbol of power of Minangkabau indigenous people, can be called as a republican power. Soekarno is referred to as the "desir d'etre ensemble", ${ }^{15}$ which is a large family that has an integrated value structure in a Minangkabau culture. Therefore, the reason strong enough to

13 Glen Wright, "Indegenous People and Customary Land Ownership Under Domestic Redd Framework : A Case Study of Indonesia", LEAD Journal (Law, Environment and Development Journal), 2011, Vo. 7/2, hlm. 125

14 Thomas E. Davitt dalam penelitiannya di berbagai negara terkait dengan hukum primitive (hukum kebiasaan), menunjukkan bahwa hukum kebiasaan yang berlaku di tengah-tengah masyarakat tradisional hanyalah nilai-nilai yang berkaitan dengan kepentingan individu-individu dalam kelompok tersebut. Nilainilai tersebut tidak bersifat universal, sehingga ia tidak diberlakukan universal untuk seluruh kelompok masyarakat. Thomas E. Davitt, Nilai-Nilai Dasar di Dalam Hukum, Menganalisa Implikasi-Implikasi Legal-Etik Psikologi \& Antropologi Bahi Lahirnya Hukum, 2012, Yogyakarta, Pallmal Yogyakarta, hlm. 41

15 Safroeddin Bahar dan Nannie Hudawati (ed), Loc. Cit 
confirm this view is that Nagari was first born of the Pagaruyung Kingdom. His relationship to the power of the Pagaruyung Empire was not hierarchical and the imperial power rushed to the small areas. Nagari is autonomous, because it is more concerned about the tribe and the people who are under his control. And the number of people who are genealogical in the Nagari region is a minimum of 8000 to 18.000 population. As stated by Imran Manan ${ }^{16}$ "the traditional authority of the king of Minangkabau seems to be only a symbol of unity of the Minangkabau Minangkabau republics and the maintenance of relations with people outside the Minangkabau realm". Further stated Wendra Yunaldi, "The kingdom of Minangkabau therefore not also as a symbol of power center that nourish Nagari. Nagari and the Pagaruyung Kingdom are like two sides in one coint, each standing alone bunch by Minangkabau custom ". Therefore, Nagari in West Sumatra never experienced life in a feudalistic power system.

Living in a society that has never experienced a feudalistic culture, is able to foster philosophical values such as deliberation, consensus, mutual cooperation, communalism and unity. This conception is then adopted by Article 18 of the 1945 Constitution that is the traditional root of Nagari customary law community in Minangkabau. Some of the characteristics of the democratic social system of the Nagari community in Minangkabau, according to Wendra Yunaldi ${ }^{17}$ taking into account several traditions that have taken place in Nagari society since the beginning, are:

1. have a philosophy of life

2. have a clear identity

3. sovereign

4. the nature of togetherness (communal)

5. religious

6. authority

7. decency

8. tepa slira

9. harmony

10. gotong royong

11. the objective and accepted objective legal order

12. clear and legitimate leadership

13. supervised, controlled and responsible leaders

14. representative and representative representation bodies

15. deliberation in decision making. ${ }^{18}$

According to G. Kartasapoetra, ${ }^{19}$ history has proven that all the traditional legal or community

16 Imran Manan, Birokrasi Modern dan Otoritas Tradisional di Minangkabau (Nagari dan Desa di Minangkabau, 1995, Padang, MRC FPTK IKIP Padang, hlm. 43

17 Wendra Yunaldi, "Rekonstruksi Regulasi Kesatuan Masyarakat Hukum Adat Nagari yang Berbasis Keadilan Dalam Bingkai Negara Kesatuan Republik Indonesia, Disertasi, 2017, Semarang, Universitas Islam Sultan Agung, hlm. 158

18 Ibid., hlm. 152-153

19 G. Kartasapoetra, Desa dan Daerah dengan Tata Pemerintahannya, 1986, Jakarta, Bina Aksara, hlm. 119120 
associations of our ancestors have always shown the will to:

1. Always tolerate

2. Always participate

3. Always help out and in an atmosphere of unity

4. Always actively combining unity and unity in the form of mutual cooperation, and

5. And others that show a principle that has a universal value, where one characteristic of it is"not justify the split

Koentjoro Poerbopranoto ${ }^{20}$ states: Regarding the original elements of democracy still in the indigenous communities throughout Indonesia, BJ Haga in his book "Indonesische en Indische democratic" has meticulously collected and examined the materials in each of the indigenous peoples he learned and came to a conclusion that in Indonesia there really is a kind of "eastern democracy.

The term eastern democracy certainly affirms the differences of democracy that exist in Indonesia with the democratic ideas that are in the Netherlands, so that B.J. Haga came to that conclusion. Soetardjo by looking at deliberations and meetings held by villagers as the embodiment of democracy based on the One Godhead, according to the philosophy of "Manunggalnya Kawulo Gusti". ${ }^{21}$ Three things can be understood from Soetardjo's opinion, that is, first, put the human (meeting participants) in the same position, parallel and not caste, and secondly, the absence of authoritarian decision-making and without involving the interested community, and third, and involvement of all stakeholders in the village to make an agreement for the common good.

Nagari in West Sumatra, better known as the nagari republic, ${ }^{22}$ has regional and adat powers as well as integrated. I.H.DT.R. Penghulu ${ }^{23}$ states:

....Indigenous democracy in Minangkabau is not according to Western mathematics, Minangkabau democracy is sovereign to the people, its roots deeply into the hearts of society. Therefore, he is souveran, native and has its own personality, Minangkabau democracy united with the fairy of people's life, the philosophy of the people's life studied by nature ... This is Minangkabau democracy whose wadjahnya imagine in the composition of society, pendjel maan from the customs and laws that from the beginning become fixed in a long pole, anchored to a simmering sea, as rising with smoke, as with the dew.

20 Koentjoro Poerbopranoto, Sistim Pemerintahan Demokrasi, 1987, Bandung, PT. Eresco, hlm. 82

21 Soetardjo Kartohadikoesoemo, Desa, 1984, cet, ke-1, Jakarta, PN. Balai Pustaka, hlm. 221

22 Ungkapan Republik Nagari ini dipopulerkan oleh Tsuyohi Kato, dalam, Aidul Fitriciada Azhari, Rekonstruksi Tradisi Bernegara Dalam UUD 1945, 2014, Bantul-Yogyakarta, Genta Publishing, hlm. 35

23 I. H. DT. R. Penghulu (pen), Adat Minangkabau, 1968, t.p, t.tp, hlm. 121 


\section{Making Authentic And Independent Democratic Politics Indonesia}

$\mathrm{Hatta}^{24}$ stated that "the Indonesian political joints consist of two forms, namely the sovereignty of the people and the deliberation of the people". People's sovereignty necessitates a building system in which the sovereignty of the people really manifests substantially and formally. Substantially, the values contained in it can elaborate the whole way of thinking of the elements of the nation, such as legislative, executive, judiciary and civil society to strengthen the constitutional building, especially in the application of democracy in accordance with the will of the sovereign people. The will of the sovereign people is then carried out with a model of "deliberation" as a system that eliminates differences and barriers, be they political or natural. That principle is called the political morality of the nation. Where value is more important than the way or system is formed. The political morality of the nation should be built with a family model, as Sukarno, Hatta, Soepomo and M. Yamin and almost all the founding fathers in the sessions of BPUPKI and PPKI 1945.

Excessive democracy, democratic deficit, or other terms that indicate a decline in subsistence democratic meaning today, so that democracy as a tool to realize the ideals of Indonesian nation life becomes obstructed, the structural approaches that have tended to be used by the state, both in the era of guided democracy, then in the era of Pancasila democracy and to this day when democracy lives merely the political jargon of the regime. There needs to be a new approach and awareness that started from strengthening the values of the character of local wisdom owned by indigenous peoples of Indonesia.

The model of the Nagari republic is able to provide solutions for the implementation of alternative democracy in order to reinforce the articulation of democracy in the life of the nation and the state at this time. Nagari as stated by Hazairin basically has exemplified the model of representation through the House of Representatives (DPR). ${ }^{25}$ In the concept of political representation which at the same time embodies the people's representatives, the essence of the function of the political party from which the birth of political representatives is expected to be the leader of the people in managing and solving the problems faced by society. although, it can not be denied, the interests of political parties are more precedent than the interests of the people, so what is the wishes and expectations of the people, not necessarily the wishes and expectations of political parties.

In Nagari, the leader or pengujulu incorporated in Limbago Adat as the supreme institution in power to straighten the executive, legislative and judicial policy. As the structure of Nagari put forward Wendra Yunaldi: ${ }^{26}$

24 Mohammad Hatta, Demokrasi Kita, Pikiran-Pikiran tentang Demokrasi dan Kedaulatan Rakyat, 2009, cet, ke-2, Bandung, Sega Arsy, hlm. 60

25 Hazairin, Demokrasi Pancasila, 1985, Jakarta, Bumi Aksara, hlm.55

26 Wendra Yunalid, Op.Cit., hlm. 454 


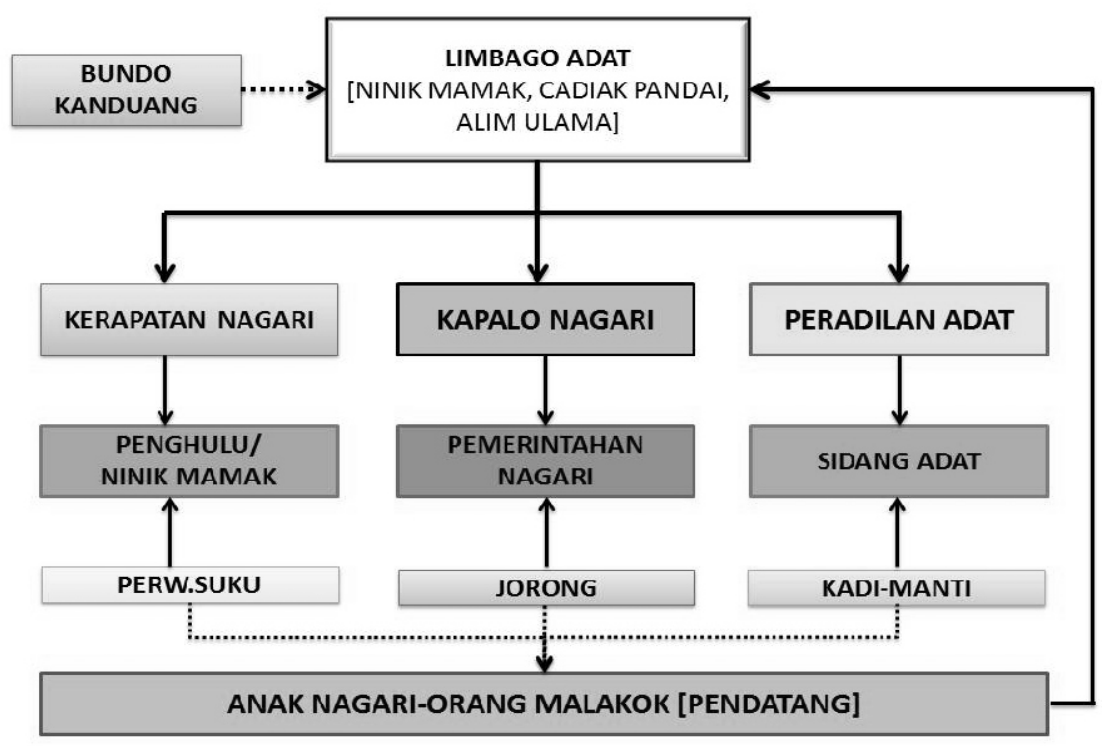

Ninik mamak meetings in Lembaga Adat, in addition to resolving tangles (problems) among the three elements, they are also a place of complaint for the community for the actions and policies taken by the elements of the nagari. Thus, with their position of direct representation of their people (tribes), elements such as the legislature, the judiciary, and the executive, because of the legitimetious disconnect on them, the three institutions are very cautious and pay attention to the decisions they make.

This condition is somewhat different from the position of the People's Consultative Assembly (MPR), with members consisting of members of DPR and DPD, inevitably the political intervention in its policy is inevitable. The people are difficult, if it is not possible to directly complain to the MPR. The authority of the MPR as regulated in Article 2 and 3 of the 1945 Constitution of the Republic of Indonesia, the MPR is only authorized to amend the Constitution and then to inaugurate and dismiss the President. The People's Consultative Assembly (MPR) does not have the authority of the people to remedy the mistake, whether it be the President, the DPR, the DPD or the judiciary. These state institutions are independent and the MPR has no authority to voice the aspirations of the people, when these state institutions fail to carry out their duties to realize the expectations of the people. Simple cases are seen in the absence of accountability when planned programs fail to be implemented by the President, Governor, or Regent / Mayor in his tenure, or they are unable to satisfy the public. The President or the regional head, when it failed to materialize the expectations of the people, was solely linked to political sanctions. Which because of the failure they can not be considered to have committed unlawful acts.

When using Robert A. Dahl's perspective on democracy, in the model adopted by Nagari, 
equality, active participation, truth-proclaiming, final control of the agenda and coverage, have not been implemented. The absence of these basic principles is due to the current model of representation, more to the effort of co-opting legitimacy by political institutions.

For the three aspects of Dahl's perspective above, namely participation, transparency and control by the people against the government (state), tend to be weak. People's aspirations and participation have been represented to the DPR and DPD. In the modern political system, this representative institution works in the interests of the people who empower them to follow the aspirations and wishes of the people. In the third thesis, Meyer,: Political Parties translate the value and importance of a society in a bottom-up process * so that the values and interests of that society become the draft state laws, binding regulations, and programs for the people. ${ }^{27}$ However, seeing the current political dynamics, the relationships between the representatives (political parties) and the people, are only limited to five years of political contestation, after which the representatives (political parties) are busy with their internal political interests in relation to power. Although, the activities of members of the People's Legislative Assembly in the form of a recess to their electoral districts, such activities are no more merely ceremonial.

Unlike the democratic model developed by the leaders in Nagari, they are always present in the pulse of aspirations and the problems faced by the people (tribes). It is they who sometimes ask for a high meeting in Limbago Adat to resolve the kusuik (dispute) that occurs within the tribe and the people. According to Emeraldi Chatra: in his position as a community leader, a penghulu is no longer a free individual in behaving ... it may even be said to be silent on his own behalf or exhibit anarchist attitudes." ${ }^{28}$ B.J Haga as Koentjoro pointed out, the element of traditional democracy in Indonesian custom is partly a "democratie directe", in which customary chiefs together with elected representatives, constitute a council of adat officials. ${ }^{29}$

In terms of expressing aspirations and control over power. The principle of democracy in Nagari establishes its authority based on the principles of kinship and mutual cooperation. Even though, the public has the right to voice aspirations and evaluate the performance of their leaders, all done in polite and civilized ways, bajanjang ride batanggo down. That is, open participation for all communities and individuals open opportunities to voice things that are perceived to be detrimental to their interests. However, everything is done in ways that are customary, that is using the principle alua jo patuit (propriety). Because, on the basis of the principle of chaos, any evaluation and criticism given is not to destroy, but in order to maintain straightness and responsible attitude. Because, from wrongful deeds that are fatal will harm the common interest. As M. Nasroen puts it: the happiness of a person with and within it is

27 Thomas Meyer, Op.Cit, hlm.30

28 Emeralid Chatra, Adat Selingkar Desa, 1999, Padang, Fisipol dan PSP2SB Unand, hlm. 22

29 Koentjoro Poerbopranoto, Op.Cit., hlm. 85 
achieved on the basis of the form and composition of society based on the principle of, by and for cohesion also ...

Based on the above description, Indonesian democratic character of local wisdom is basically very likely to be developed in this democratic political tradition in modern times. The purpose of democracy is not solely on the realization of representative political institutions, but also, to fulfill the will of political behaviour living in society. this perspective is what the founders of the country call the political morality of the Indonesian nation. And that morality, very rich is contained in the value structure and cultural system that lives in Indonesia, one of them, like Nagari. Branded clothes can be made in america, but kerpibadian must be made in Indonesia. ${ }^{30}$

\section{Closing}

The democracy of local wisdom as embodied in Nagari in Minangkabau teaches about the meaning of democracy as a model of political life that synergizes the institutional interests of the state with the values $\square \square$ of morality. State institutions that are void of value, and disregard the role of value in their systems, tend to be a tool of power that negatively affects democracy itself. And on the other hand, will increasingly marginalize the sovereign people in the political order.

\section{BIBLIOGRAPHY}

Aidul Fitriciada Azhari, Rekonstruksi Tradisi Bernegara Dalam UUD 1945, 2014, BantulYogyakarta, Genta Publishing

Bagir Manan, Beberapa Masalah Hukum Tata Negara Indonesia, 1997, Bandung, Alumni

Dahl, Robert A., Analisa Sistem Politik Modern, terjemahan, Sahat Simamora, dari judul, Modern Political System, Bumi Aksara, Jakarta, 1985

,Demokrasi dan Para Pengkritiknya, terjemahan, Yayasan Obor Indonesia, dari judul, Democracy and Its Critics, Yayasan Obor Indonesia, Jakarta, 1992

, Dilema Demokrasi Pluralis, Antara Otonom dan Kontrol, terjemahan, Sahat Simamora, dari judul, “Dilemmas of Pluralist Democracy” Rajawali, Jakarta, 1985

Davitt, Thomas E., Nilai-Nilai Dasar di Dalam Hukum, Menganalisa Implikasi-Implikasi Legal-Etik Psikologi \& Antropologi Bahi Lahirnya Hukum, 2012, Yogyakarta, Pallmal Yogyakarta

Emeralid Chatra, Adat Selingkar Desa, 1999, Padang, Fisipol dan PSP2SB Unand

30 M. Nasroen, Dasar Falsafah Adat Minangkabau, 1971, Djakarta, Bulan Bintang, hlm. 70 
Wendra Yunaldi : Democracy "Character" Local Wisdom Building Democratic Political .....

G. Kartasapoetra, Desa dan Daerah dengan Tata Pemerintahannya, 1986, Jakarta, Bina Aksara

Hazairin, Demokrasi Pancasila, 1985, Jakarta, Bumi Aksara

Huntington, Samuel P., Partisipasi Politik di Negara Berkembang, terjemahan, Sahat Simamora, dari judul, No Easy Choice : Political Participation In Developing Countries, Rineka Cipta, Jakarta, 1990

I.H. DT. R. Penghulu (pen), Adat Minangkabau, 1968, t.p, t.tp

Imran Manan, Birokrasi Modern dan Otoritas Tradisional di Minangkabau (Nagari dan Desa di Minangkabau, 1995, Padang, MRC FPTK IKIP Padang

Johnston, Wiliam D. Halsey and Bernard (eds), Collie's Encyclopedia, New York : Macmilan Educational Company, 1988

Koentjoro Poerbopranoto, Sistim Pemerintahan Demokrasi, 1987, Bandung, PT. Eresco

M. Nasroen, Dasar Falsafah Adat Minangkabau, 1971, Djakarta, Bulan Bintang

Meyer, Thomas, Peran Partai Politik dalam Sebuah Demokrasi, 2012, Jakarta, FriedrichEbert-Stiftung (FES)

Mohammad Hatta, Demokrasi Kita, Pikiran-Pikiran tentang Demokrasi dan Kedaulatan Rakyat, 2009, cet, ke-2, Bandung, Sega Arsy

Safroeddin Bahar dan Nannie Hudawati (ed), Risalah Sidang Badang Penyelidik UsahaUsaha Kemerdekaan Indonesia (BPUPKI) dan Panitia Persiapan Kemerdekaan Indonesia (PPKI) 28 Mei 1945-22 Agustus 1945, 1998, Jakarta, Sekretaria Negara Republik Indonesia

Soetardjo Kartohadikoesoemo, Desa, 1984, cet, ke-1, Jakarta, PN. Balai Pustaka

Uhlin, Anders, Oposisi Berserak: Arus Deras Demokratisasi Gelombang Ketiga di Indonesia, terjemahan, Rofik Suhud, dari judul, Indonesian and The Third Wave of Democratization The Indonesia Pro Democracy Movement in Changing Word, Mizan, Bandung, 1998, cet, ke-2

Wendra Yunaldi, "Rekonstruksi Regulasi Kesatuan Masyarakat Hukum Adat Nagari yang Berbasis Keadilan Dalam Bingkai Negara Kesatuan Republik Indonesia, Disertasi, 2017, Semarang, Universitas Islam Sultan Agung

Wright, Glen, "Indegenous People and Customary Land Ownership Under Domestic Redd Framework : A Case Study of Indonesia”, LEAD Journal (Law, Environment and Development Journal), 2011, Vo. 7/2 